\title{
PODER Y REPRESENTACIÓN EN LAS FIESTAS EFÍMERAS: LA ENTRADA TRIUNFAL EN POTOSÍ DEL VIRREY-ARZOBISPO MORCILLO ${ }^{1}$
}

\author{
Mariana C. Zinni(a)
}

POWER AND REPRESENTATION IN EPHEMERAL FESTIVALS: THE

TRIUMPHAL ENTRY OF VICEROY ARCHBISHOP MORCILLO INTO POTOSÍ

PODER E REPRESENTAÇÃO NAS FESTAS EFÊMERAS: A ENTRADA

TRIUNFAL EM POTOSÍ DO VICE-REI E ARCEBISPO MORCILLO

Fecha de recepción: 24 de septiembre del 2020

Fecha de aprobación: 20 de octubre del 2020

Disponible en línea: 9 de diciembre del 2020

Sugerencia de citación:

Zinni, M. C. (2021). Poder y representación en las fiestas efímeras: la entrada triunfal en potosí del virreyarzobispo morcillo. Razón Crítica, 10, 33-59. https://doi.org/10.21789/25007807.1701

(1)

Parte de la investigación de este artículo fue financiada con una beca otorgada por PSC-CUNY en el verano del 2018..

(a) Mariana C. Zinni

Ph. D. en Lenguas y Literaturas Hispanas, University of Pittsburgh

Profesora asociada de Queens College, Estados Unidos.

https://orcid.org/0000-0001-8105-4710

mariana.zinni@qc.cuny.edu 


\section{R E S U M E N}

En este estudio se propone el análisis de determinados artefactos iconográficos, que se erigen con motivo de celebrar la entrada triunfal del recién nombrado virrey interino arzobispo Don Diego de Morcillo y Auñón, a la Villa Rica del Cerro de Potosí, de paso rumbo a Lima. Tales artefactos, los magníficos arcos triunfales, mascaradas, una loa y hasta un cuadro al óleo, comisionado a Melchor Pérez de Holguín, se diseñan con antelación; el objetivo es exaltar la figura del virrey, plasmando las figuras emblemáticas acostumbradas. Se propone la lectura de algunos aspectos del programa iconográfico producido en torno a la figura de Morcillo, con el objeto de dilucidar rasgos locales y de la agencia criolla en Potosí, desplegada cuidadosamente en estos emblemas.

PALABRAS CLAVE: entrada triunfal; emblemas; potosí; virreinato del Perú; virrey-arzobispo Morcillo. 


\section{A B S T R A C T}

This work studies certain iconographic artifacts erected to celebrate the triumphal entry of the recently appointed interim Viceroy, Archbishop Diego de Morcillo y Auñón, to Villa Rica del Cerro de Potosí, on his way to Lima. Such artifacts, the magnificent triumphal arches, masquerades, a play (loa), and even an oil painting, commissioned to Melchor Pérez de Holguín, were designed in advance. Their purpose was to exalt the figure of the Viceroy by embodying emblematic artistic figures. This research proposes the reading of certain aspects of the iconographic program produced around the figure of Morcillo in order to elucidate local features and some characteristics of the creole agency in Potosí, carefully displayed in these emblems.

KEYWORDS: triumphal entry; emblems; Potosí;

Viceroyalty of Peru; Viceroy Archbishop Morcillo.

\section{R E S U M O}

Neste estudo, é proposta a análise de determinados artefatos iconográficos que surgem em razão da celebração da entrada triunfal do recémnomeado vice-rei interino arcebispo dom Diego de Morcillo y Auñón na Villa Rica del Cerro de Potosí, de passagem a Lima. Tais artefatos -magníficos arcos triunfais, mascaradas, salva de elogios e até um quadro a óleo, comissionado a Melchor Pérez de Holguín- são elaborados com antecedência; o objetivo é exaltar a figura do vice-rei, plasmando as figuras emblemáticas acostumadas. É proposta a leitura de alguns aspectos do programa iconográfico produzido em torno da figura de Morcillo, com o objeto de dilucidar traços locais e da agência crioula em Potosí, desenvolvida cuidadosamente nesses emblemas.

PALAVRAS-CHAVE: entrada triunfal; emblemas; Potosí; vice-reinado do Peru; vice-rei e arcebispo Morcillo. 


\section{LA FIESTA VIRREINAL: LA VILLA IMPERIAL SE GELEBRA A SÍ MISMA}

Las fiestas virreinales - tanto civiles como eclesiásticas- sirven para ilustrar distintos momentos de la relación entre la metrópolis y sus colonias. Resulta de sumo interés estudiar estas celebraciones, sobre todo si se producen en centros urbanos alejados de la cabeza virreinal. En el caso que nos ocupa, en Potosí, ciudad periférica, pero de suma importancia en el virreinato del Perú; a las numerosas celebraciones eclesiásticas se le suma una que, por su carácter de inédito, conviene analizar en extenso. El 25 de abril de 1716 hizo su entrada triunfal el recién electo virrey interino del Perú, el arzobispo con sede en Charcas, don Diego Morcillo y Auñón. Esta entrada dio pie a fiestas y celebraciones en la Villa Rica, que duraron ocho días, incluyendo banquetes, mascaradas, toros, luminarias, una loa, refrigerios, desfiles y demás despliegues acostumbrados. Lo excepcional es la ocasión: Morcillo, quien accede al poder luego de la renuncia del virrey interino anterior, el arzobispo de Quito don Diego Ladrón de Guevara, pasa por Potosí rumbo a Lima para asumir el poder temporal, en espera de la llegada del nuevo virrey, el príncipe de Santo Buono.

El arribo del arzobispo-virrey causó alboroto en la Villa Imperial, aunque no fue esta su primera estancia potosina. Como arzobispo, Morcillo visitó la ciudad en septiembre de 1713, "saliéndole a recibir toda la Villa, que no cabían por los campos y calles la multitud de sus moradores y fue cosa que no se vio en otras entradas de príncipes eclesiásticos" (Arzáns, 1965, p.8). El cronista describe el arco triunfal confeccionado para la ocasión, así como también los espectáculos musicales, los adornos de plata labrada y las colgaduras con que se engalanaron las calles y casas principales, y el magnífico banquete celebrado en las casas de la mina de 
Cotamito, donde se hospedaba. Durante esta primera visita, Morcillo subió al Cerro Rico ${ }^{1}$ invitado por los opulentos azogueros, quienes contribuyeron con toda la grandeza y liberalidad posible a la ocasión, obsequiándole 500 marcos de plata. Tres años más tarde, siendo los vecinos más ricos de la Villa, fueron partícipes fundamentales de su nueva visita, la entrada triunfal de Morcillo como virrey interino del Perú.

En la ocasión anterior, Morcillo prometió restaurar y cumplir con el pacto establecido entre los azogueros y la corona española, sobre la cantidad de indios aceptables en la explotación minera, garantizando el pago de los reales quintos, pero sin la limitación de emplear solo cinco mil indios, número restringido por Real Cédula en 1697 por perjuicio que, la utilización de los mismos en las minas, causaba en la actividad agropecuaria en la zona de Charcas. Se comprometió a revertir esta situación y volver a las épocas en las que se podían emplear hasta veinte mil indios en las minas. La llegada del, esta vez, arzobispo-virrey resultaba una buena oportunidad para activar una máquina laudatoria, a través de los festejos de bienvenida, pensando en primera instancia en el futuro del gobierno y en los beneficios potosinos, pero también como aparato divulgador de los intereses criollos por excelencia, enfatizando el presente de la ciudad y sus particulares necesidades. Esa fue una de las razones por las cuales el gremio de los azogueros festejó con largueza la vuelta del prelado, esta vez empuñando la vara regia.

Las múltiples celebraciones que se erigen en torno a la llegada de un virrey, suelen ser categorizadas como uno de los epítomes de la fiesta barroca, donde se homenajea sobre todo una ausencia, la del rey encarnada en su vicario ${ }^{2}$. Tal evento es considerado un tiempo de excepción, una cesura efímera que sirve como alivio al tedio cotidiano, sobre todo en ciudades periféricas como Potosí, donde la rutina solo es

1 Morcillo es el segundo funcionario de alto nivel en subir al cerro (el virrey Toledo lo hizo en el marco de su extensa visita general de 1570 y 1575): "Jueves que se contaron 19 de octubre fue el señor arzobispo a ver el rico Cerro de esta Villa, tanto porque lo convidó el ilustre gremio de azogueros, cuanto por curiosidad suya y convenir la vista de su propia persona para lo que pretendía... Fue cosa jamás vista en Potosí que un príncipe de la Iglesia fuese al Cerro, que por lo que toca a seculares el virrey don Francisco de Toledo no sólo subió a él, mas también entró a las minas" (Arzáns, 1965, p. 9).

2 La bibliografía sobre la fiesta mundonovista es muy extensa. Véase Acosta de Arias (1997), Alberro (1998), Barriga-Tello (2007), Bravo-Arriaga (2002), Buxó (2007), Cajías de la Vega (2003), Farré-Vidal (2013), Hanke (1956), Inch (1980), López-Cantos (1992), Merrim (2010), Mínguez (2010), Ramos-Sosa (1992), Rubial-García (2009), Voigt (2009, 2016), entre otros. Sobre la "entrada del virrey", véase Abdallán Conde Flores (2014), Bromley (1953), Cañeque (2004,2007), CárdenasGutiérrez (2002), Herzog (1997), Morales-Folguera (2009,1991), Moreno-Cebrián (2001a,b), Osorio (2004) y Wuffarden (1999). 
interrumpida por las abundantes fiestas religiosas. La ciudad se viste con sus mejores galas y se celebra a sí misma, teatralizando el espacio urbano, erigiendo arcos, adornando las calles, planeando vistosas representaciones y mascaradas. La fiesta como tiempo excepcional, participa tanto de la vida virreinal como de la metropolitana, ya que "apunta a desapegar a los hombres de sus historias locales, de sus ritmos étnicos, de sus calendarios nacionales, a fin de integrarlos a los tiempos sincronizados y homogéneos del mundo" (García-Icazbalceta, 1971, p. 162). En este sentido, Antonio Maravall analiza la interrupción que la fiesta causa en la vida cotidiana como "lo oscuro y lo difícil, lo nuevo y desconocido, lo raro y extravagante, lo exótico, todo ello entra como resorte eficaz en la perceptiva barroca que se propone mover las voluntades, dejándolas en suspenso, admirándolas, apasionándolas por lo que antes no habían visto” (1975, p. 467).

Fiestas como las entradas de virrey, según analiza Farré Vidal, suelen dar cuenta de "un mayor derroche económico, que se traduce en una declarada búsqueda de efectismo, que pretende hacer más memorable lo extraordinario de la celebración” (1992, p. 12). Los gastos, parte esencial de la fiesta, fueron en este caso exorbitantes, pese a las regulaciones y prohibiciones estipuladas para este tipo de celebraciones, ya que las ciudades atravesaban grandes penurias económicas, que provocaban profundas deudas una vez apagados los fastos ${ }^{3}$. Por lo general, se sigue un guion muy estructurado y esquemático, repitiendo los mismos elementos a lo largo de los años, en especial las fiestas religiosas, en las que se utilizan una y otra vez los mismos decorados, símbolos, andas, etc. Las fiestas repentinas son más propensas a introducir variantes locales, por tratarse de circunstancias especiales en la vida colonial. En el caso de la muy codificada entrada de virrey — la construcción de arcos triunfales, el uso del palio, la procesión que acompaña a la autoridad a lo largo de su recorrido por las calles adornadas, el solemne Te Deum Laudamus ofrecido en la iglesia mayor, los banquetes, juegos, toros y mascaradas- ${ }^{4}$, el tinte local se da de manera más marcada, pese al poco tiempo que se tiene para preparar la celebración, no solo por la importancia del acontecimiento,

3 Los límites en los gastos estipulados para este tipo de ceremonia se pueden encontrar en las Leyes de Indias, bajo el Título Tercero. De los Virreyes, y Presidentes Gobernadores, donde se estipula un máximo de 12000 pesos en las ciudades cabeza de gobierno, y que incluyen todos los elementos de la fiesta: decoración y limpieza, regalos, espectáculos, banquetes y colaciones, etc. 4 Sobre arcos triunfales, véase Alberro (2001), Bonet-Correa, (1990), Bravo-Arriaga (2002, 2005), Cañeque (2007), Castaño-Navarro (2007), Méndez-Bañuelos (2007), Mínguez (2017, 2009), Morales-Folguera (1991, 2017, 2013), Ramos-Sosa (1992) y Voigt (2009,2016). Sobre las corridas de toros en fiestas potosinas, véase Castillo-Martos (2003). 
sino porque se presta para presentar auspiciosamente la ciudad a los ojos del nuevo mandatario. La fiesta sirve, en primera instancia y a nivel local, para posicionar a la ciudad al reivindicar su propio espacio simbólico, a través del recorrido y los adornos, la magnificencia y el regalo, y a la vez presentar la imagen que una sociedad muestra de sí misma, donde el protagonista excluyente es el orgullo criollo. En el caso de Potosí, esto se expresó, en principio, en el excesivo gasto, un modo de dejar bien alta la reputación de una ciudad a menudo asociada con la avaricia y el pecado.

El exceso se traduce en deseos de buen gobierno, en la necesidad de reforzar determinados valores y en posibles favores para la Villa Imperial, la cual, si bien portentosa y magnífica, no deja de ser periférica en relación con Lima, la cabeza del virreinato, y los caminos que a ella conducen. La opulencia de la entrada triunfal afirma la imagen que se tiene a priori del virrey, en tanto que buen gobernante. Todo el aparato iconográfico diseñado para la solemne ocasión es cuidadosamente pensado para alabar y adular al virrey entrante, proclamando las prendas morales indispensables para llevar a cabo su tarea, y al mismo tiempo, con el objetivo de definir y delinear el poder del virrey, "moldeándolo" hacia los intereses locales.

En Potosí se construyeron dos arcos triunfales, ciento veinte arcos de plata "de mano" que atravesó el cortejo rumbo a la Iglesia Mayor, se vistieron los veinticuatros ${ }^{5}$ con lujosos vestidos de terciopelo y se impuso un palio de plata y tisú nácar. Era costumbre del virrey rechazar el palio, pero Morcillo no solo lo utilizó, sino que además se lo llevó de regalo a su patria ${ }^{6}$, al igual que la peana de plata con la icónica forma del Cerro Rico de Potosí y que se puede encontrar actualmente en la Ermita de Nuestra Señora de la Caridad en Villarrobledo, ciudad natal de Morcillo, beneficiada largamente por su caridad. Se le entregó al virrey entrante, como era la usanza, un caballo ricamente enjaezado, se ofrecieron banquetes y colaciones, y una intrincada mascarada; se limpiaron y adornaron las calles con luminarias y enramadas, hubo juego de cañas y toros, castillos y fuegos artificiales. Los azogueros, por su parte, además de costear el espectáculo taurino, la colación y los licores que se sirven a

5 La veinticuatría es un cargo municipal, equivalente al de regidor o concejal, propio de algunas ciudades de la España del Antiguo Régimen, ligado a la nobleza y posición social de quien lo ostenta. Su origen está relacionado con la conquista de Granada por los Reyes Católicos, quienes dieron a guardar las puertas de la ciudad a veinticuatro capitanes, caballeros de probada hidalguía, quienes quedaron como guardianes y regidores.

6 Sobre el uso, abuso y controversias respecto del palio en las entradas virreinales, véase Cárdenas-Gutiérrez (2002) y Cañeque (2004). 
continuación, le regalaron al arzobispo cincuenta mil pesos de plata y le entregaron cien mil pesos más, para que el virrey pagara en Lima una deuda contraída con el gobernador de Huancavélica ${ }^{7}$. Arzáns señala que la fiesta costó unos 100000 pesos en galas, libreas, arcos, y banquetes. De presentes (en marcos de plata y joyas) se agregaron 50000 pesos más. Estos gastos fueron solventados casi en su totalidad por el cabildo y los gremios, sobre todo el de los azogueros, puesto que no había dinero en la Villa para pagar los ocho días de magníficos festejos. Aun en este tiempo "tan calamitoso", como no duda de calificarlo el cronista, se llevó a cabo la lujosa entrada, financiada con la riqueza minera y la explotación del indígena en la mita, pese a las necesidades económicas del resto de los habitantes de la villa.

\section{EL APARATO ICONOGRÁFICO EN LA FIESTA VIRREINAL}

Lo visual en las fiestas, tanto repentinas como las del calendario litúrgico o civil, resulta un factor determinante: establecer un mensaje iconográfico para ver y hacer ver elementos específicos que se pretenden resaltar, así como también verse y dejarse ver en las celebraciones que interrumpen la por momentos monótona vida de las ciudades virreinales. Tal parece ser el cometido principal de estas celebraciones, donde lo visual estaba siempre del lado del lujo y del exceso, de lo artificial y lo magnífico. Como era costumbre, se adornan las casas y balcones, se limpian las calles y se las cubre de enramadas y flores, se estrenan vestidos y libreas, caballos enjaezados y carruajes lustrados, y se iluminan las noches con castillos y fuegos artificiales, y, sobre todo, se presta especial atención a lo iconográfico, vehículo de la celebración y elementos descritos en las interminables y prolijas crónicas que relatan los sucesos.

Este tipo de fiestas, proclamadas como suerte de celebración liminal, puerta de entrada a las nuevas responsabilidades de gobierno, define la expectativa puesta en el nuevo virrey, exalta las virtudes del príncipe e introduce determinados lineamientos en la administración del poder. El

7 Huancavélica era la principal proveedora del indispensable mercurio, para llevar a cabo el necesario proceso de amalgama a la hora de extraer la plata del mineral crudo recabado del cerro. Sobre el problema de las minas potosinas y la relación con Huancavélica, véase Bakewell (1975, 2009), Bridikhina (2008,2007), López-Beltrán (1991), Moreno-Cebrián (2001b) y Pearce (1999). Sobre la particular situación de la mita potosina a la llegada de Morcillo, véase Moreno-Cibrián (2001), Crespo-Rodas (1955) y Mira (1999). 
programa propagandístico resulta esencial para cumplir tal cometido, por lo que se hace necesario desplegar un programa iconográfico a futuro, que elogie al virrey antes de que comience a ejercer el poder. En este sentido, la fiesta no se plantea como una forma de exaltación de acciones realizadas de antemano, sino que proyecta el ideal de buen gobierno que se espera del nuevo mandatario (Farré-Vidal, 2013). El arco, elemento privilegiado para presentar este programa, se lee como "manual efímero del buen gobernante" (Cañeque, 2007), y el festejo se convierte en un speculum princeps, espejo de príncipes, que adquiere su concreción más sofisticada por medio del emblema ${ }^{8}$.

Es providencia estimable el que a los príncipes sirvan de espejo, donde atiendan a las virtudes con que han de adornarse los arcos triunfales que en sus entradas se erigen para que de allí sus manos tomen ejemplo, o su autoridad y poder aspire a la emulación de lo que en ellos se simboliza en los disfraces de triunfos y alegorías de manos [...] no son estas fábricas remedo de los arcos que se consagraban al triunfo, sino de las puertas por donde la ciudad se franquea [...] Providencia será también el que a la vez primera que a los príncipes y gobernadores se les franquean las puertas sean cuando en ellas estuviesen ideadas las virtudes de los mayores, para que, depuesto allí todo lo que en ellas no conviniese, entren al ejercicio de la autoridad y del mundo adornados de cuantas perfecciones se les proponen para ejemplar del gobierno (Sigüenza \& Góngora, 1984, p. 171).

Mujica Pinilla (2016) aduce que ya a partir del siglo XviI se manejaban en el Perú láminas y divisas de textos como Emblemata Evangelica de Hans Bol (1585), Amoris Divina Emblemata de Otto van Veen (1600), Schola Cordis de Benedictus van Haeften (c. 1640), o los Pia Desideria de Hugo Hermann (1624). El uso inaugural del emblema en el Nuevo Mundo ocurrió en el Túmulo Imperial compuesto por Francisco Cervantes de Salazar en 1560

8 Por emblema, de manera general, nos referimos al género literario surgido en 1531 de la mano de Alciato y su Antología Planudea, publicada con ilustraciones del pintor Breuil, bajo el título Emblematum Libellus. Aquilino Sánchez define los emblemas como "cantos o epigramas a los que se añaden imágenes, simbolizaciones que explican con erudición y variedad” (Sánchez, 1977, p. 170). La bibliografía sobre el emblema es extensa y compleja. A modo de introducción, véase Nelson (2010), Ledda (2000) y Sánchez-Aquilino (1977). Para el estudio del uso de emblemas en el Nuevo Mundo, véase Leal (2017), Mínguez (2017), Ossorio (1989) y Querejazu-Escobari (2007). Sobre los mitos clásicos y la literatura emblemática, véase Lamarca Ruiz de Eguílaz (1994), Morales-Folguera (2013) y García-Arránz (2017). 
con motivo de los funerales de Carlos V. En poco tiempo la fiesta barroca - los funerales regios son la fiesta por excelencia para tal cometidose transformó en el medio ideal para difundir la cultura del emblema e incorporarla a la vida colonial. Víctor Mínguez señala que la cultura emblemática en América rebasará el libro para proyectarse "hacia todas las manifestaciones artísticas, ya fuera arte de calidad o popular, provisional o perenne, político o religioso, público o privado” (2010, p. 110). López Parada, por su parte, sugiere respecto de la apropiación de la tradición emblemática en la América hispánica que

la utilización del emblema fuera de su ubicación natural era una práctica instituida a partir del éxito sin precedentes de Alciato y de sus numerosos seguidores en todas las lenguas y en todas las variedades simbólicas, morales, amorosa, divinas o militares que pueda imaginarse: algo que hace del género una categoría mimetizable y abierta, con flexibilidad demostrada para la mutación, el pluriempleo y la diversidad (2018, p. 321).

Cuando el emblema se sale de libro y se plasma en la arquitectura efímera de la celebración, deviene vector de propaganda (Gruzinski, 2010, p. 40). El emblema, de por sí formidable aparato didáctico, se convertirá en las colonias en una manera de producir una imaginería criolla por medio de una retórica sofisticada, que parte de un código compartido y se cristaliza en un lenguaje eminentemente político donde se produce un recorrido figural, suerte de discurso persuasivo. "La enumeración de virtudes atribuidas al virrey (propias de un príncipe perfecto) no solo comprometía a la autoridad con un modelo de comportamiento político, sino que buscaba inducir las acciones de gobierno hacia asuntos que los emisores del arco consideraban más convenientes para el virreinato" (Buxó, 2007, p. 276). La empresa recaerá entonces en crear un programa iconográfico adecuado en el cual los emblemas escogidos se conviertan subrepticiamente en un manual de instrucción política: esto es, diseñar un mensaje político de carácter local a partir de una configuración alegórica compleja.

Es la ocasión, pues, de temporizar esta emblemática; de darle circunstancia, sentido de la utilidad real y marco a aquello que superficialmente parece remitirnos a valores eternos e inespecíficamente situados en una dimensión extra histórica. Al 
contrario de lo que hasta aquí ha sucedido, es el momento para esforzarse en demostrar en tales obras la pertenencia al código de clase, aristocrática, nobiliaria, que lo utiliza como moneda de circulación en el territorio mental y físico que domina (Rodríguez de la Flor, 2012, p. 118).

De este modo, cuando el emblema se aplica a la fiesta, nos encontramos ante un medio de comunicación poderosísimo, a través del cual es posible corporizar el mensaje que se quiere transmitir a partir de una serie de artefactos construidos exclusivamente para la ocasión, que a la vez resultan pertinentes tanto al sujeto que se representa como a quienes lo representan.

Ante la llegada de un nuevo virrey se produce una renovación del pacto político entre las colonias y la metrópolis. La fiesta, sobre todo el programa iconográfico desplegado en primer lugar en los arcos triunfales erigidos para la ocasión, adquiere un sentido particular en los mensajes que muestra, sus implicancias ideológicas, un plan de gobierno y una identidad criolla en ciernes, que también se manifiesta en otros elementos, como por ejemplo en las loas que se componen, o en los espectáculos teatrales, mascaradas y desfiles. Estos arcos, siempre espectaculares y de carácter laudatorio, formaban parte de la arquitectura efímera de la celebración, pensados para causar asombro, y al mismo tiempo, medios para enviar mensajes políticos a partir de la complejidad alegórica que exhibían (Buxó, 2007). El arco, bien leído, era un texto más de los representados en la ceremonia, un texto erudito, pensado en clave emblemática y con un solo destinatario, el nuevo gobernante:

El arte efímero no era subestimado en la época virreinal [...] Ello se debía a que era utilizado como una 'arquitectura parlante'. Este arte buscaba entablar una comunicación directa y ejercer una contundente propaganda visual sobre el pueblo que observaba el desfile. Los cuadros alegóricos que se exponían transmitían ideas claras del poder colonial [...] Pero dichos arcos también le recordaban al nuevo mandatario los fueros y libertades que tenía la obligación de respetar (Angeli, 2011, p. 85).

El arco, puerta y espejo, "Demóstenes mudo" en palabras de Sor Juana Inés de la Cruz, tiene siempre una función política ambivalente en la celebración, sobre todo si atendemos a la necesidad de modelar, definir 
y delinear le poder del virrey, junto con sus atribuciones morales, a la vez que exponer sutilmente los intereses locales por medio de los bien pensados emblemas. El arco, entonces, se presenta como una empresa política y las imágenes desplegadas, espejo moral en el que el príncipe debe reflejarse.

El emblema, elocuente de por sí, tomaba muchas veces el ribete del exemplum, pero con parámetros firmemente controlados. Se trataba de diseñar, por medio de una metáfora que identificara al nuevo gobernante con un personaje de la antigüedad, una alegoría a partir de la cual se reconocía una serie de virtudes planteadas como modelo y esperanza de buen gobierno. Los arcos eran el vehículo más adecuado para plasmar los emblemas. Cañeque analiza su diseño no solo como "as an act of flattery or as simply an opportunity to further one's personal career, but as the realization of one of the most important functions any seventeenthcentury educated person could aspire to, that of giving advice to his or her prince" (2004, p. 34). En estos términos, los arcos se pensaban como como instrumentos de control, revestidos de poderosos símbolos políticos y cristianos, verdaderos tratados altamente visibles, aunque no necesariamente legibles para todos. Indicaban las virtudes esperables en un príncipe cristiano, como es el virrey (acentuado en nuestro caso por la doble autoridad que ostenta Morcillo, quien además es arzobispo) con la esperanza de que fueran guías señeras en su gobierno: caridad, justicia, prudencia, liberalidad y clemencia.

Por lo general, se utilizaba la mitología clásica para reflejar las virtudes del homenajeado, mientras que la historia romana reflejaba el espejo de príncipes. A partir de las disposiciones del Concilio de Trento, se prohíbe identificar a los virreyes con personajes bíblicos, puesto que no se podían "utilizar historias sagradas para asuntos profanos" (Reglas, Xvi) y conviene recurrir a héroes y dioses de la antigüedad para expresar sus bondades y genealogía. Entre 1640 y 1696 fue frecuente la utilización de héroes del panteón clásico para representar al virrey: Mercurio, Prometeo, Hércules, Perseo, Marte, Ulises, Apolo, Atlas, Eneas, Júpiter, Neptuno, Pan, Castor, Paris, Jano, Proteo (Mínguez, 2004). Para Gruzinski, “los mitos ofrecían sutiles, indirectos y disfrazados modos de expresar conceptos que criticaban el poder político y la autoridad del soberano” (1997, p. 365), por lo cual, los modelos escogidos representaban una intervención de parte de la ciudad celebrante en el diseño del plan de gobierno del virrey entrante.

Los artefactos erigidos en torno al virrey Morcillo — arcos, mascarada, loa, e incluso el lienzo de Pérez de Holguín—, todos de 
carácter emblemático, seguían con esta retórica del espejo de príncipes, donde ilustraban, por un lado, las virtudes del príncipe cristiano ideal, y por el otro, proyectaban un ideal de gobierno y programaban la identidad del mismo. En Potosí se erigieron dos arcos triunfales, fabricados con prisa y utilizando materiales aún más endebles que los acostumbrados, pues, como señala Arzáns, "la brevedad del tiempo no lo dio más de a suplir la falta de pincel para fingir los jaspes y mármoles, el oro y colores, con vestirlos de preciosas telas, costosos bordados y ricas sedas" (1965, p. 47). El primer y principal arco, el más adornado, se emplazó en la calle que lleva a la parroquia de San Martín y es el que aparece en el lienzo de Pérez de Holguín. Por lo general, este arco es el primero que atraviesa el agasajado. Convertido en ese momento en virrey, representaba las puertas de la ciudad y del gobierno, y en su interior se solía llevar a cabo la solemne ceremonia del juramento y toma de poder. En Potosí no sucedió tal cosa, no se trataba de la entrada principal a la capital del virreinato, sino de un paso. El segundo arco se colocó en la esquina de la calle del Contraste, en la Plaza de Regocijo, cerca del solar de don Francisco Gambarte, donde se hospedaría Morcillo.

Los arcos potosinos no parecen ser excesivamente ricos ni muy alegóricos debido a la urgencia. Arzáns se contenta con describir el tamaño, la cantidad de cuerpos y naves, la altura, las molduras, algunos materiales, como sedas y follajes, los espejos, la imagen de la Fama, pero no las figuras alegóricas que lo adornan. Comenta “varias imágenes de bulto repartidas en los cuatro ángulos, unas esmaltadas y otras con ropas de tela y brocado, en significación de las virtudes morales de su excelencia ilustrísima” (1965, p. 47), y las “diferentes tarjas en los medios de las cornisas de inscripciones que declaraban los jeroglíficos, empresas y emblemas apropiados a su excelencia ilustrísima” (1965, p. 47). Corre por cuenta del lector imaginar cuáles son tales virtudes. Fray Juan de la Torre, en su pasión ecfrástica, describirá el primer arco con algo más de detalle, mencionando los elementos utilizados, como espejos, brocados, encajes de oro y plata, finos paños de colores, etc. (1716, f. 9). Como veremos, el aparato iconográfico se trasladará a otro medio, al lienzo que el sobrino de Morcillo encargará a Pérez de Holguín en recuerdo de los eventos y que fuera destinado al mismo virrey. Lo que sí describe el cronista, manifestando su orgullo criollo, son las riquezas y dignidades de la ciudad, haciendo hincapié en la corona que dio en la cabeza del arzobispo una vez atravesado el primer arco, los niños, caracterizados como "Urbanidad y Liberalidad, virtudes muy propias de esta Imperial Villa” (Arzáns, 
1965 , p. 47), la belleza de las damas potosinas apostadas en ventanas y balcones, y los 120 arcos de plata labrada de mano que se levantaron al paso del virrey.

Las referencias a personajes mitológicos y su identificación con el arzobispo-virrey corren por cuenta de Fray Juan, quien escribe una loa, parte de la Aclamación festiva de la muy noble imperial villa de Potosí, en la dignísima promoción del Excelentísimo Señor Maestro don Fray Diego Morcillo Rubio y Auñón, obispo de Nicaragua y de La Paz, Arzobispo de las Charcas, al gobierno de estos reinos del Perú, por su virrey y capitán general, y relación de su viaje para la ciudad de Lima, firmada por él, el 26 de junio de 1716 y publicada con licencia en Lima por Francisco Sobrino. El padre agustino define a Morcillo a partir de la doble genealogía del poder que ostenta, simbolizado en el cayado de pastor y el bastón de mando: Josué y Moisés, ambos emblemas del buen gobierno, y como el Sol Sagrado, que encuentra su cenit en Potosí $i^{9}$.

\section{La emblemática aplicada en un lienzo de Pérez de Holguín}

Quizás el artefacto más interesante, en términos iconográficos, de la entrada de Morcillo a Potosí sea el lienzo que compuso en 1718, un año más tarde de los festejos, Melchor Pérez de Holguín, el pintor más insigne y prolífico de la Villa Imperial. El lienzo, titulado "Entrada del Arzobispo Virrey Morcillo en Potosí” (1717), única pintura profana que se le conoce al artista y de dimensiones considerables -4 metros de largo por 2 de ancho-, fue comisionado por el sobrino de Diego Morcillo, Pedro Mexía Morcillo, en agradecimiento por el nombramiento como visitador y vicario general de Charcas, para que fuera exhibido en España. Este cuadro se puede leer como el "reverso" de los textos de Arzáns — quien curiosamente no nombra a Pérez de Holguín, pese a que este fue testigo presencial de los fastos- y de fray Juan de la Torre. En él vemos muchos de los personajes mencionados por ambos textos, crónica y loa, individualizados y reconocibles entre los participantes de la procesión, como anotan de Mesa y Gisbert (1977, 1952), quienes señalan la valía del cuadro en lo que respecta a la arquitectura efímera erigida para la ocasión, un testimonio de las costumbres, ropas, adornos, y edificios y construcciones potosinas que no se han conservado en la actualidad.

9 Para un análisis detallado de la loa y del particular campo semántico utilizado por fray Juan, véase Zinni (por publicar). 
El espacio pictórico está dividido en tres escenas. La procesión regia por la calle San Martín, una vez atravesado el primer arco de triunfo, conforma la superficie más grande y destacada. En la escena central vemos el segundo arco triunfal, el arzobispo bajo palio con gesto de bendecir, exponiendo así su doble autoridad — arzobispo y virrey, pastor y gobernante señalado por fray Juan-, y la acostumbrada procesión que acompañaba al virrey, compuesta por los veinticuatros y toda la comitiva de notables con sus respectivas libreas, suerte de exhibición de lo que Cañeque denomina "politics of proximity" (2004, p. 136), los balcones atiborrados de gente que vitorea al paso del cortejo e incluso algunos personajes en la calle. En este sector de la pintura, y casi en el centro del lienzo, vemos un autorretrato de Pérez de Holguín de cuerpo entero, sosteniendo una paleta con un pincel y una inscripción que dice "Melchor Pérez de Holguín, mester". En la parte superior encontramos dos viñetas, como si el pintor hubiera querido retratar varios eventos al mismo tiempo para expresar de manera más completa los acontecimientos: a la derecha, la llegada del virrey a la iglesia matriz y a la izquierda, la mascarada de los mineros representada en la Plaza del Regocijo. En la primera viñeta encontramos a Morcillo bajo palio a punto de entrar en la iglesia matriz, donde se celebrará el solemne Te Deum Laudamus, recibido por el vicario, los monaguillos y los representantes del clero secular y regular. En la segunda, el despliegue de personajes participantes de la mascarada, un carro triunfal con un niño vestido a la manera del arzobispo y Morcillo mismo observando, suerte de mise-en-scéne, desde los balcones de la residencia donde se hospedaba.

En este artefacto, complejo aparato discursivo en sí mismo, podemos "leer" una serie de críticas y advertencias al virrey que cobran nuevo sentido al conocer lo que sucedió luego de la visita. Para el presente estudio, me interesa centrarme en los aspectos emblemáticos del cuadro, ubicados en los siete lienzos que el pintor incrustó, como adorno de balcones y fachadas. En ellos vemos una sucesión de escenas que acompañan a Morcillo en su recorrido: Ícaro caído, Eros y Anteros, Mercurio, una escena de la fábula de Endimión, la muerte alada y a caballo, el coloso de Rodas, y finalmente, Eneas y Anquises huyendo de Troya. El énfasis en la utilización de la mitología griega, como ya señalamos, debería estar al servicio de remarcar los "méritos" de Morcillo y en acentuar el carácter civil de la celebración. Veremos que esta vez no se trata de resaltar méritos, sino de aconsejar y advertir al virrey, único destinatario del programa iconográfico diseñado para la ocasión. 
La disposición de emblemas en la fiesta —Ledda define esta función de la iconografía en un contexto festivo como una "emblemática aplicada" (2000, p. 251) - marca el paso, un recorrido figural equivalente a un discurso persuasivo. Los organizadores de la fiesta entendían la composición emblemática en tanto que estructura compleja, teniendo en cuenta una eficacia comunicacional, que resulta ser un medio muy poderoso para el mensaje político, en este caso, acuñado exclusivamente para Morcillo, ya que, recordemos, fue encargado por su propio sobrino para gloria de la familia. El primer lienzo que se ve en el camino de la procesión, y el más cercano al virrey, representa la figura de Ícaro, hijo de Dédalo, ambos confinados en la isla de Creta. El padre inventa un artefacto para salir de la isla, unas alas de pluma unidas con cera con las que remontarían vuelo y saldrían de la isla-cárcel. Dédalo, símbolo de la prudencia, logra mantener un curso de vuelo sin acercarse al sol, que derretiría la cera y le haría caer, ni al océano, pues la humedad del agua haría más pesadas las plumas. En cambio, el hijo, Ícaro, llevado por la soberbia, se acerca imprudentemente al sol, lo que conllevaría su caída al mar. Ícaro y Dédalo ilustran una máxima moral de conducta, en la cual la ambición es buena pero solo en su justa medida. Un dato que vale la pena señalar es que fray Juan, en su Aclamación festiva compara los destellos que se desprenden del segundo arco triunfal con los fuegos solares, poniendo al virrey en lugar de un pseudo-Faetón que correría peligro si no tomaba los recaudos y prudencia necesarios para guiar el carruaje, el cual, en este caso, se identificaría con el buen gobierno (f. 16v). Tenemos aquí la primera advertencia al codicioso virrey.

La siguiente imagen muestra a Eros y Anteros, ambas figuras relacionadas con el amor. En el caso de Anteros, con el amor virtuoso y correspondido, amor que le dispensa Potosí a su recién estrenada autoridad, y quien, a diferencia de su hermano Eros, representa una visión del amor en tanto que relaciones a largo plazo, con emociones más profundas y menos caóticas y pasionales que su joven compañero. Cuando aparecen juntos, como en este caso, ambos se regulan y equilibran las fuerzas del amor. En tanto que deus ultor de Eros, Anteros es quien venga a las víctimas de los amores no correspondidos, provocados por los flechazos unilaterales de la deidad del amor pasional. Anteros, en tanto que deseo de ser correspondido, se ajusta a la aspiración potosina de entablar una fructífera relación a largo plazo con el arzobispo-virrey.

El cuadro siguiente pone a a Mercurio y Argos en el camino del cortejo. Mercurio parece tener un lugar central y un mensaje claro: no solo 
es el emisario de los dioses, el protector del comercio y los comerciantes, dios de la abundancia en los negocios y la prosperidad comercial, sino que también personifica a los azogueros, aquellos que utilizan del mercurio (azogue) en las minas de plata. Argos Panoptes, el gigante de los cien ojos, es el guardián, el vigilante que todo lo ve y todo lo vigila, duerme cerrando la mitad de sus ojos, mientras que los otros permanecen despiertos, alertas. Juntos remiten al episodio que relata Covarrubias y que tiene una interpretación emblemática complementaria: Mercurio tañe la flauta para dormir al gigante y matarlo, y poner así de manifiesto la moraleja: no prestar oído a voces aduladoras y engañosas, puesto que las dulces palabras encarnan un grave peligro. Quizás Pérez de Holguín exprese aquí una crítica a los azogueros que lisonjearon al virrey con regalos y plata en sus dos visitas a la Villa.

Las imágenes que siguen son las más oscuras en relación con el posible significado atribuible al programa emblemático pensado para Morcillo. El cuarto lienzo ilustra la escena de la conocida fábula de Endimión a punto de caer inerme, flechado por Eros a pedido de Selene, enamorada del joven que elige permanecer dormido, bello e inmortal, sueño del cual solo sale para recibir a su amada. En este caso, no habría una representación mitológica que podamos relacionar con la figura del virrey. A Endimión le sigue el Coloso de Rodas, tal vez una alegoría de las necesidades edilicias de la villa. Por su parte, también puede leerse como faro y guía: será el virrey quien dirigirá la política y el futuro del virreinato mientras dure su mandato. En el siguiente retrato vemos la muerte, alada y a caballo, en obvia referencia a la mortalidad y la finitud de los tiempos y complementaria de Cronos, el tiempo que corre y se acaba, señalando que el virrey es un hombre ya mayor, tiene 74 años —y una envidiable energía- al asumir el interinato ${ }^{10}$.

El séptimo y último lienzo que adorna el recorrido del virrey tiene como protagonista a Eneas huyendo de Troya llevando en brazos a su padre Anquises, símbolos del viaje y la fortaleza, de la sabiduría y prudencia con que esquivar los peligros que llevan a una nueva patria, y también de la benevolencia con los impedidos. Es un emblema ciertamente popular, utilizado por Alciato, que representa el amor filial por sobre el amor a la patria (Eneas salva a su padre llevándolo en andas) y el

10 Morcillo prueba ser longevo. Asume su segundo virreinato, esta vez plenipotenciario, en 1720, a los 80 años de edad. Gobierna por cuatro años y muere en Lima en 1730, todavía desempeñándose como arzobispo metropolitano, puesto que ocupaba desde 1723. 
amor al prójimo que hace desdeñar los peores temores, como señalara Covarrubias. Eneas es el primero en honrar a los suyos y otra de las representaciones de la prudencia.

El héroe troyano es motivo frecuente en la emblemática mundonovista, por lo que podemos imaginar que Pérez de Holguín está embebido de un contexto simbólico, como vemos a lo largo de los siete lienzos, y la iconografía escogida no es novedosa o inédita, sino conocida y fácilmente legible en el contexto. Como tema popular, la vemos en al menos dos entradas de virrey, la de Hurtado de Mendoza en Lima en 1590 y en la del marqués de Mancera en México en 1664. En el primer caso, en el arco erigido para la entrada del virrey a la capital peruana:

Eneas, que representaba la persona del virrey, iba caminando por medio de la mar con una espada desnuda por báculo. El mote decía: Aquae multae non potuverunt / Extinguere pristina. Que dice: ni la muchedumbre de las aguas que había de por medio, ni la distancia del lugar, fueron bastantes para causar en mí algún olvido de este reino, al cual he llegado por el valor de mi brazo y virtud (Pacheco, 1867, p. 318).

Esta frase resuena con aquella pronunciada por Morcillo cuando parte de la Villa Imperial rumbo a Lima una vez finalizados los festejos: "Harto me ha dado Potosí, yo me acordaré de su liberalidad" (Arzáns, 1965, p. 49).

Más compleja fue la utilización de su figura en la entrada del marqués de Mancera. En un Elogio panegírico compuesto por don Alonso Ramírez de Vargas en 1664, Eneas corporiza la figura de un príncipe "cristiano" piadoso y cumplidor de sus promesas, un hombre cabal, prudente y medido (1664, f. 5r) capaz de vencer a las Harpías [“ambición, avaricia y escasez" (1664, f. 7r)], ya que "del Príncipe es forçosa esta obligación, de desterrar de sí y de los suyos semejantes vicios" (1664, f. 7v). En el Elogio, Anquises es la joya de más estima: su hijo elije salvarlo llevándolo en andas, poniendo en peligro a su hijo y esposa debido a la necesaria ralentificación de la huida emprendida. En la traslación simbólica, Eneas aprende de Anquises las artes del buen regir, a la vez que el padre representa el peso infatigable del gobierno en hombros del hijo, quien no torcerá su camino ni aún en estas circunstancias: "A Anchises tu cuydado / en ombros supo sacar / ayudándole a llevar / del gobierno lo pesado." (Ramírez, 1664, f. 3v). Y es Eneas quien promete premios a los méritos (Virgilio, trad. 2017), a la vez que sortea las adulaciones, los llantos y palabras ligeras (Ramírez, 
1664, f. 9v). Ramírez de Vargas indica que "[m]edirse deben las fuerzas con el peso de los méritos, y ninguno puede adjudicarse honores a sí propio, menos que a obediencias de su dueño" (1664, f. 8r). Y agrega:

Todo esto está significado, que a la rectitud, igualdad, y entereza de nuestro Excellentíssimo Virrey, serán vanas diligencias para anublarla, la adulación y demás achaques, que suelen empañar a las Repúblicas; y más quando soberanos auxilios le animan, en quienes tiene puesta la mira su christianíssimo celo (1664, f. 10r).

En la interpretación pictórica de Pérez de Holguín, y siempre recordando que los lienzos, al parecer, fueron añadidos a posteriori —no tenemos testimonio ecfrástico de los mismos, ni grabados que ilustren los arcos triunfales y demás parafernalia en la loa de fray Juan, quizás por los costos de edición que esto supondría- ${ }^{11}$, Morcillo está lejos de Eneas y la idea de buen gobierno. De hecho, al virrey se lo sitúa espacialmente junto a Ícaro cayendo al mar, símbolo de la imprudencia. Los regalos mal habidos, las adulaciones, las fallas de su breve regencia, están representados en las negociaciones espurias entre Morcillo y los azogueros -Argos, Mercurio, Ícaro-, y en especial, el dinero que se lleva el virrey con promesas vanas, pese a que hace votos de no olvidarse de Potosí y su liberal recibimiento.

\section{CONCLUSIONES}

Conviene leer este aparato iconográfico a la luz de los sucesos inmediatamente posteriores, puesto que buena parte de los emblemas, sobre todo los incrustados en el lienzo de Holguín, se completaron un poco después del solemne recibimiento. El interinato de Morcillo duró lo que un suspiro: camino de Lima, a pocas horas de haber salido de Potosí, recibió la noticia que el nuevo virrey, Carmine Caracciolo, príncipe de Santo Buono, ya estaba de camino a la capital virreinal, a donde arribarían prácticamente al mismo tiempo. El arzobispo, furioso, decide volver a

11 Arzáns describe la ciudad engalanada y dice que al paso del virrey se han puesto cuidados extremos en lo que refiere al adorno: "La distancia desde el arco triunfal a la iglesia mayor es dilatada, y con ser así todos los balcones, ventanas, puertas y cruceros se habían cubierto de innumerable gente, y las paredes de uno y otro lado de arriba abajo adornadas de ricas y varias colgaduras de rasos, terciopelos, y otros mis tapices de seda y paños de corte, de telas y damascos, cuadros de primorosos pinceles, países y retratos" (Arzáns, 1965, pp. 47 y ss, énfasis añadido), pero no describe los cuadros o retratos emplazados en las casas. 
Charcas, frustrando así las esperanzas de los azogueros. Fray Juan de la Torre hace eco de esta desazón:

Divulgóse la noticia junta con la resolución de su Excelencia, y divididos en pareceres los más, efecto común no lo popular de qualquier no prevenido accidente, unos temían se frustraba la esperanza que en el zelo y experiencia de su Excelencia fundaban del remedio prompto de esta villa $(1716$, f. $30 \mathrm{v})$.

La crónica de Arzáns también alude a los negocios con el virrey y al pesimismo general: "Dejó varios decretos y confirmaciones de cargos, no pensando los pretensores su breve duración” (1965, p. 52). Asimismo, cabe recordar que Morcillo se llevó los dineros y obsequios presentados ${ }^{12}$, incluso el palio, "con que por varias maneras fue su venida de gravísimo daño a esta villa” (Arzáns, 1965, p. 52) ${ }^{13}$.

Volviendo al objetivo de nuestro trabajo, es a través del emblema, concebido como manera de experimentar el poder, que el poder mismo resulta desarticulado y cuestionado (Nelson, 2010). Si el emblema o el proyecto iconográfico diseñado para la entrada virreinal es capaz de definir y promover conceptos de buen gobierno, resulta ser un elemento fundamental a la hora de moldearlo desde las elites coloniales, celebrando a la vez la presencia del poder imperial ausente, pero presente en la figura del virrey (Cañeque, 2004). De esta manera, será posible codificar las bases para un nuevo gobierno, a través de este espejo de príncipes en el que se tallan las cualidades morales necesarias al buen gobernante. Pero también es un vehículo privilegiado para expresar críticas, advertencias y consejos al príncipe. En estos términos, el emblema, en manos de los criollos, se convierte en un instrumento de crítica al poder, modo de desnudar las fallas y también en suerte de contrapropaganda.

La fiesta, su motivo y estructura, forman parte del plan de dominación cultural español, pero los criollos utilizarán estos elementos

12 En un gesto "altruista", Morcillo intenta devolver los regalos de los azogueros, a sabiendas de que estos no serán recibidos. Responde uno de los caballeros "que la nobleza y la liberalidad de aquellos señores no cabía en volverlos a recibir aunque no les quedase más de una sola camisa” (Arzáns, 1965, p. 53).

13 Este daño no fue solo económico, sino también moral: además de los onerosos gastos que asumió el cabildo, el exhibicionismo y exceso de lujo de Potosí quedaron expuestos, así como los artilugios que pergeñaron algunos habitantes para no pagar las costas de la fiesta. Por ejemplo, Francisco Tirado, sale de la Villa antes de la llegada de Morcillo, viaja a La Plata para ser uno de los primeros en adular al nuevo virrey, y no aportar dineros para la fiesta mientras gana posiciones al estar físicamente en la sede arzobispal. 
para acuñar y enviar su propio mensaje en medio del boato y la pompa acostumbradas, exacerbadas en este caso por la riqueza que es capaz de desplegar la Villa Imperial. En consecuencia, Potosí se celebra a sí misma, al cerro y las riquezas, sus habitantes y urbanidad, y a su vez, a través de un cuidadosamente diseñado programa iconográfico, la Villa advierte a Morcillo, desplegando una iconografía más cercana, en el planteo emblemático, a la imprudencia de Ícaro que al buen gobierno. A la vez, señala la falla: el arzobispo-virrey no es Eneas, tampoco Moisés o Josué. Y agrega que la muerte se vislumbra en el horizonte cercano y que los regalos que se lleva tienen un objetivo claro, más allá de la adulación de los mineros. En este sentido, la fiesta sirve como excusa para manifestar un mensaje, un pedido y una advertencia al virrey: la Villa Imperial, lejos de su momento de gloria y en franca decadencia de la producción de plata, sigue siendo fuente de riquezas y de ella dependen, en buena medida, las finanzas del imperio. Solucionar los inconvenientes acarreados con la mita y el problema del mercurio con Huancavélica haría un gran servicio la corona, para lo que se necesita la intervención del virrey. Por lo tanto, Morcillo, como buen gobernante, debe guardar sus promesas y apaciguar su codicia. Sin embargo, esto no sucede y el objetivo de la fiesta se malogra.

Una vez más recurrimos a Arzáns para resumir la sensación de desasosiego y decepción general:

[Recibió] el bastón de virrey de estos reinos el ilustrísimo, reverendísimo y excelentísimo señor don fray Diego Morcillo Rubio de Auñón, arzobispo de La Plata, el cual (aunque su ascenso fue tan breve que pasó como sueño o como sombra y con tales circunstancias que acreditaron ser una farsa todo lo de este mundo) con todo eso le pondremos en el número 26 de los virreyes del Perú (Arzáns, 1965, p. 46).

Siguiendo el tenor de esta cita, vemos que los gastos excesivos de los fastos en honor al virrey resultan vanos. Como espejo de príncipes deformado a posteriori y en la periferia, la fiesta fracasa. La concepción de la entrada virreinal, siempre pensada a futuro, y con el objetivo de mostrar y mostrarse, de promover fidelidad al nuevo gobernante, accediendo al celebrado de manera inédita - recordemos que no es frecuente que las máximas autoridades virreinales pasen por las tierras altas- deviene entonces en una serie de consejos y advertencias al virrey expresados en 
la iconografía de la fiesta, quien supo leerlos en su momento y, de alguna manera, reaccionar resolviendo algunos de los asuntos pendientes en su segundo virreinato.

\section{REFERENCIAS}

Acosta de Arias Schreiber, R. M. (1997). Fiestas coloniales urbanas (Lima- CuzcoPotosi). Otorongo.

Alberro, S. (1998). Imagen y fiesta barroca: Nueva España, siglos XVI-XVII. En P. Schumm (Ed.), Barrocos y modernos. Nuevos caminos en la investigación del Barroco latinoamericano (pp. 33-48). Iberoamericana.

Alberro, S. (2010, enero-marzo). Los efectos especiales en las fiestas virreinales de Nueva España y Perú. Historia Mexicana, 59(3), 837-875. https://www.redalyc. org/articulo.oa?id=60015915001

Angeli, S. (2011). Retratando el microcosmos colonial. Melchor Pérez de Holguín y la Entrada del arzobispo Virrey Morcillo a Potosí. Atrio, 17, 77-90. https:// www.upo.es/revistas/index.php/atrio/article/view/549

Arzáns de Orsúa, \& Vela, B. (1965). Historia de la Villa Imperial de Potosí (Eds. L.

Hanke \& G. Mendoza). Brown University Press.

Bakewell, P. (2009). Minners of the Red Mountain. Indian Labor in Potosi, 1545-1650.

University of New Mexico Press.

Barriga-Tello, M. (2007). De Fiestas y fiestas en el siglo xviı virreinal. En J.

P. Buxó (Ed.), Reflexión y espectáculo en la América virreinal (pp. 439-457).

Universidad Nacional Autónoma de México.

Bonet-Correa, A. (1990). Fiesta, poder y arquitectura. Aproximaciones al barroco español. Akal.

Bravo-Arriaga, M. (2002). Festejos, celebraciones y certámenes. En R. Chang-

Rodríguez (Coord.), Historia de la literatura mexicana desde sus orígenes hasta nuestros días. La cultura letrada en la Nueva España del siglo XVII (Vol. II, pp. 85114). Siglo xxı; Universidad Nacional Autónoma de México.

Bravo-Arriaga, M. (2005). La fiesta pública: su tiempo y su espacio. En A. Rubial-

García (Coord.), Historia de la vida cotidiana en México. La ciudad barroca (Vol. II, pp. 435-460). Fondo de Cultura Económica; El Colegio de México.

Bromley, J. (1953). Recibimiento de virreyes en Lima. Revista Histórica, 20, 5-108.

Cajías de la Vega, F. (2003). La fiesta barroca en Potosí. En Barroco Andino.

Memorias del I Encuentro Internacional (pp. 75-64). Unión Latina.

Cañeque, A. (2004). The King's Living Image. The Culture and Politics of Viceregal Power in Colonial Mexico. Routledge.

Cañeque, A. (2007). Espejo de virreyes: El arco triunfal del siglo xviı como manual efímero del buen gobernante. En J. P. Buxó (Ed.), Reflexión y espectáculo en la América Virreinal (pp. 198-218). Universidad Nacional Autónoma de México. 
Cárdenas-Gutiérrez, S. (2002). Las insignias del rey: disciplina y ritual público en la Ciudad de México (siglos XVI-XVII). Jahrbuch für Geschichte Lateinamerikas 39, 193-216. https://doi.org/10.7767/jbla.2002.39.1.193

Cárdenas-Gutiérrez, S. (2008). Ius Truimphandi: La primera entrada de los virreyes, una institución de derecho público en Nueva España. En M. TorresAguilar (Coord.), Actas del XV Congreso del Instituto Internacional de Historia del Derecho Indiano (Vol. II, pp. 1369-1393). Diputación de Córdoba; Universidad de Córdoba.

Castaño-Navarro, A. (2007). Sermones, explicaciones de arcos y comentarios literarios: géneros afines en el contexto de la fiesta novohispana. En J. P. Buxó (Ed.), Reflexión y espectáculo en la América Virreinal (pp. 219-230). Universidad Nacional Autónoma de México.

Castillo-Martos, M. (2003). Toros en el altiplano andino (1550-1650). Una aproximación a su historia. En A. García-Baquero \& P. Romero (Coords.), Fiestas de toros y sociedad: actas del Congreso Internacional celebrado en Sevilla del 26 de noviembre al 1 de diciembre del 2001 (211-234). Universidad de Sevilla. Castro-López, O. (2002). Los símbolos del orbe novohispano [Prefacio]. En J. P. Buxó, (Ed.) El resplandor de las imágenes. Estudios de emblemática y literatura novohispanas (pp. 9-19). Universidad Nacional Autónoma de México.

Chiva-Beltrán, J. (2012). El triunfo del virrey. Glorias novohispanas: origen, apogeo y ocaso de la entrada virreinal. Publicaciones de la Universidad Jaume I. https:// doi.org/10.6035/America.2012.29

Conde-Flores, L. (2014). Espacios escénicos en las fiestas de entrada de virreyes. Nueva España. Siglo XVII (Tesis de Maestría). Universidad Nacional Autónoma de México. https://ru.dgb.unam.mx/handle/DGB_UNAM/TES01000723884

Crespo-Rodas, A. (1955). La mita en Potosí. Revista Histórica, 22, 169-182.

Curcio-Nagy, L. (2004). The Great Festivals of Colonial Mexico City. Performing Power and Identity. University of New Mexico Press.

De Covarrubias, S. (2006). Tesoro de la lengua castellana o española. Iberoamericana; Vervuert.

De la Torre, J. (1716). Aclamación festiva de la muy noble imperial villa de Potosí, en la dignísima promoción del Exmo. Señor Maestro Don Fray Diego Morzillo Rubio y Auñón, Obispo de Nicaragua y de la Paz, Arçobispo de las Charcas, al Gobierno de estos Reynos del Perú, por su Virrey y Capitán General, y Relación de su Viage para la Ciudad de Lima. Francisco Sobrino.

Farré-Vidal, J. (2013). Espacio y tiempo de fiesta en Nueva España (1665-1760). Universidad de Navarra; Iberoamericana; Veruvert; Bonilla Artigas. https:// doi.org/10.31819/9783954872404

García-Arranz, J. (2017a). An Approach to the Emblematic and Allegorical Culture in the Viceroyalty of Perú. En P. Leal \& R. Amaral Jr. (Eds), Emblems in Colonial Ibero-America. To the New World to the Ship of Theseus (Vol. 18, pp. 185228). Glasgow Emblem Studies.

García-Arranz, J. (2017b). Un bestiario para celebrar: fauna simbólica en la fiesta barroca del virreinato del Perú. Quiroga. Revista de Patrimonio Iberoamericano, $11,30-41$. 
García-Icazbalceta, J. (Ed). (1971). Colección de documentos para la historia de México. Porrúa.

González de Zárate, J. (1987). Emblemas regio-políticos de Juan de Solórzano. Tuero.

Gruzinski, S. (1997). Entre monos y centauros. Los indios pintores y la cultura del Renacimiento. En B. Ares \& S. Gruzinski (Eds.), Entre dos mundos. Fronteras culturales y agentes mediadores (pp. 349-372). csic.

Gruzinski, S. (2010.) Las cuatro partes del mundo. Historia de una mundialización. Fondo de Cultura Económica.

Hanke, L. (1956). The 1608 fiestas in Potosí. Boletín del Instituto Riva-Agüero, 3, 107 128.

Herzog, T. (1997). La presencia ausente: el virrey desde la perspectiva de las élites locales (Audiencia de Quito, 1670-1747). En P. Fernández-Albaladejo (Ed.), Monarquía, imperio y pueblos en la España moderna (pp. 819-826). Universidad de Alicante.

Horozco, J., \& Covarubias de Leyva, J. (2017). Trescientos emblemas morales. Universidad de Zaragoza.

Inch, M. (1980). El rostro festivo de la Villa Imperial (siglos XVI-XIX). En Academia Boliviana de Historia, Anales de la Academia Boliviana de la Historia (pp. 127149). La Academia.

Lamarca Ruiz de Eguilaz, R. (1994). Acerca de la importancia del mito en la literatura emblemática. Jano, una iconografía al servicio del poder. Boletín de Arte de Málaga, 59, 33-55.

Ledda, G. (2000). Estrategia y procedimientos comunicativos en la emblemática aplicada (Fiestas y celebraciones, siglo xviII). En R. Zafra \& J. Aranza (Eds.), Emblemata Aurea. La emblemática en el arte y la literatura del Siglo de Oro (pp. 251262). Akal.

López-Cantos, A. (1992). Juegos, fiestas y diversiones en la América española. Mapfre.

López-Parada, E. (2018). El botón de seda negra: traducción religiosa y

cultura material en las Indias. Iberoamericana; Vervuert. https://doi.

org/10.31819/9783954876228

Maravall, J. (1975). La cultura del barroco. Análisis de una estructura histórica. Ariel.

Méndez-Bañuelos, S. (2007). Ingenio y construcción alegórica en dos arcos triunfales novohispanos. En A. Mayer (Coord.), Carlos de Sigüenza y Góngora. Homenaje 1700-2000 (pp. 35-65). Universidad Nacional Autónoma de México.

Merrim, S. (2010). The Spectacular City, Mexico and Colonial Hispanic Literary Culture. Texas University Press.

Mesa, J., \& Gisbert T. (1952). Un pintor colonial boliviano: Melchor Pérez de Holguín. Arte en America y Filipinas, 4, 149-216.

Mesa, J., \& Gisbert, T. (1977). Holguín y la pintura virreinal en Bolivia. Editorial Juventud.

Mínguez, V. (2009). Imágenes jeroglíficas para un imperio en fiesta. Relaciones. Estudios de historia y sociedad, 30(119), 81-112. http://www.scielo.org.mx/scielo. php?script=sci_arttext\&pid=S0185-39292009000300004

Mínguez, V. (2017). Emblems for a Caesar, Hieroglyphs for an Empire: Emblem Culture in the Viceroyalty of New Spain. En P. Leal, \& R. Amaral Jr. (Eds), 
Emblems in Colonial Ibero-America. To the New World to the Ship of Theseus (Vol. 18, pp. 55-93). Glasgow Emblem Studies.

Mínguez, V., Tornel, P. G., \& Moya, I. R. (2010). La fiesta barroca: Triunfos barrocos. Universitat Jaume I.

Mira, G. (1999). La minería en Potosí, las elites locales y la crisis del sistema colonial. En M. Menegus-Bornemann (Coord.), Dos décadas de investigación histórica en América Latina: Homenaje a Carlos Sempat Assadourian (pp. 401-442). El Colegio de México.

Morales-Folguera J. (1990). La emblemática en el arte religioso de Iberoamérica. En V. Mínguez Cornelles e I. Rodríguez-Moya (Eds.), Arte en los confines del imperio. Visiones hispánicas de otros mundos (pp. 199-220). Universitat Jaume I.

Morales-Folguera, J. (1991). Cultura simbólica y arte efímero en la Nueva España. Junta de Andalucía.

Morales-Folguera, J. (2009). La entrada del arzobispo Morcillo, virrey del Perú, en Potosí (1716) y las sibilas de Puebla. En J. Parrado del Olmo \& F. Gutiérrez Baños (Coords.), Estudios de historia del arte. Homenaje al profesor De La Plaza Santiago (143-148). Universidad de Valladolid.

Morales-Folguera, J. (2013). Emblemática y patrimonio en Iberoamérica. En R. López-Guzmán (Coord.), Patrimonio histórico. Difusión en imbricación americana (pp. 229-239). Universidad Internacional de Andalucía.

Morales-Folguera, J. (2017). La emblemática mística y su influencia en los programas iconográficos de Iberoamérica. Quiroga, 11, 70-80.

Moreno-Cebrián, A. (2001). La fastuosa entrada del Virrey Arzobispo Morcillo en Potosí, 1716. Torre de los Lujanes, 44, 181-205.

Moreno-Cebrián, A. (2001). Poder y ceremonial: el Virrey-Arzobispo Morcillo y los intereses potosinos por el dominio del Perú (1716-1724). Anuario del Archivo y Bibliotecas de Bolivia, 517-551.

Moreno-Cebrián, A. (2003). El regalismo borbónico frente al poder vaticano: acerca del estado de la Iglesia en el Perú durante el primer tercio del siglo xviII. Revista de Indias, 63(227), 223-274.

Moreno-Cebrián, A. (2005). Una aproximación a la corrupción política virreinal. La confusión entre lo público y lo privado en el Perú de Felipe V. Histórica, 29(1), 69-105.

Moreno-Cebrián, A., \& Vila, N. (2004). El "premio" de ser virrey. Los intereses públicos y privados del gobierno virreinal en el Perú de Felipe $V$. CSIC.

Nelson, B. (2010). The Persistence of Presence. Emblem E Ritual in Baroque Spain. University of Toronto Press. https://doi.org/10.3138/9781442660298

Osorio, A. (2004, agosto). The King in Lima: Simulacra, Ritual, and Rule in Seventeenth-Century Peru. The Hispanic American Historical Review, 84(3), 447-474. https://doi.org/10.1215/00182168-84-3-447

Osorio, A. (2006, enero-marzo). La entrada del virrey y el ejercicio del poder en la Lima del siglo xviı. Historia Mexicana, 55(3), 767-831.

Osorio, I. (1989). El género emblemático de Nueva España. En Conquistar el eco: la paradoja de la conciencia criolla (pp. 173-188). Universidad Nacional Autónoma de México. 
Pacheco, J. (1867). Del recibimiento que esta insigne cibdad hizo al virrey D. García de Mendoza. En L. Torres de Mendoza (Comp.), Colección de documentos inéditos relativos al descubrimiento, conquista y organización de las antiguas posesiones españolas de América y Ocenanía, sacados de los Archivos del Reino y muy especialmente del de Indias (Vol. 8, pp. 311-327). Imprenta de Frías.

Pearce, A. (1999). Huancavelica 1700-1759: Administrative Reform of the Mercury Indutry in Early Bourbon Peru. The Hispanic American Historical Review, 79(4), 669-702. https://doi.org/10.1215/00182168-79.4.669

Peralta-Barnuevo, P. (2001). El Júpiter olímpico. En J. Williams (Ed.), Peralta Barnuevo and the Art of Propaganda. Politics, Poetry, and Religion in EighteenthCentury Lima. Juan de la Cuesta.

Pérez de Holguín, M. (1716). Entrada del virrey Morcillo en Potosí [Óleo sobre tela]. Museo de América de Madrid.

Querejazu-Esobari, L. (2007). El programa emblemático alegórico en la entrada del virrey Morcillo a Potosí en 1716. En N. Campos (Ed.), Memoria del IV Encuentro Internacional sobre el Barroco (pp. 149-157). Unión Latina.

Ramírez-Vargas, A. (1664). Elogio Panegírico, festivo aplauso, iris político y diseño triunfal de Eneas Verdadero con que la muy noble y leal ciudad de Mexico recibió al Exmo. Señor D. Antonio Sebastian de Toledo y Salazar: Marques de Manzera, Señor de las cinco Villas y de la del Marmol: Cavallero de la Orden de Alcantara: Administrador perpetuo de Puerto Llano: del Consejo de Guerra: Virrey, Gobernador, y Capitán General de esta Nueva España, y Presidente de su Real Chancilleria, $\mathcal{E}^{2} c$. A quien lo Consagra D. Alonso Ramirez de Vargas. Viuda de Bernardo Calderón.

Ramos-Soriano, A. (2011). Los delincuentes de papel. Inquisición y libros en Nueva España. Fondo de Cultura Económica.

Ramos-Sosa, R. (1992). El arte festivo en Lima virreinal (siglos XVI-XVIII). Consejería de Cultura y Medio Ambiente de la Junta de Andalucía.

Reglas, mandatos y advertencias generales del Novissimus Librorum et Expurgandorum Index. (2013). En J. Ramos Soriano (Ed.), Los delincuentes de papel. Inquisición y libros en la Nueva España (1571-1820) (pp. 327-349). Fondo de Cultura Económica.

Rodríguez de la Flor, F. (2012). Mundo simbólico. Poética, política y teúrgia en el Barroco hispano. Akal.

Rodríguez-Hernández, D. (2007). Mitología y persuasión política: El arco triunfal en la entrada del virrey José Sarmiento de Valladares en Puebla (1696). En J. P. Buxó (Ed.), Reflexión y espectáculo en la América virreinal (pp. 273-288). Universidad Nacional Autónoma de México.

Rubial-García, A. (2009). Presencias y ausencias: la fiesta como escenario político. En M. Méndez (Ed.), Fiesta y celebración: discurso y espacio novohispano (pp. 2339). El Colegio de México.

Sánchez, A. (1977). La literatura emblemática española. Siglos XVI y XVII. Sociedad General Española de Librería.

Sigüenza \& Góngora, C. (1984). Teatro de virtudes políticas que constituyen a un príncipe. En Seis obras (pp. 167-240). Biblioteca Ayacucho. 
Virgilio. (2017). Eneida (Trad. R. Fontán Barreiro). Alianza (Obra original publicada en el siglo I a. C.).

Voigt, L. (2009). Spectacular Wealth: Baroque Festivals and Creole Consciousness in Colonial Mining Towns in Brazil and Peru. En R. Bauer \& A. Mazzotti (Eds.), Creole Subjects in the Colonial Americas: Empires, Texts, Identities (pp. 265290). University of North Carolina Press.

Voigt, L. (2016). Spectacular Wealth. The Festivals of Colonial South American Mining Towns. University of Texas Press.

Wuffarden, L. (1999). Entrada del virrey arzobispo Morcillo en Potosí. En J. Berches (Ed.), Los Siglos de oro en los virreinatos de América, 1500-1700 (pp. 146148). Sociedad Estatal para la Conmemoración de los Centenarios de Felipe II y Carlos V.

Zinni, M. (por publicar). El virrey-sol en una loa potosina de 1716. A propósito de la Aclamación festiva de fray Juan de la Torre. Pygmalión. Revista de Teatro General y Comparado, 20. Documento no publicado [Fecha posible 2021]. 